\title{
振動する 2 次元角柱に作用する変動風圧力に関する LES と実験の比較 \\ COMPARISON OF LES WITH EXPERIMENTS FOR UNSTEADY PRESSURE ACTING ON OSCILLATING 2D SQUARE CYLINDERS
}

\author{
坂本成弘 ${ }^{*}$, 持田 灯**, 村上周三*** \\ Shigehiro SAKAMOTO, Akashi MOCHIDA and Shuzo MURAKAMI
}

\begin{abstract}
The authors have examined the reliability of Large Eddy Simulation (LES) when applied to the flow analysis for unsteady surface pressure and aerodynamic forces acting on a 2-dimensional (2D) fixed cylinder. This paper deals with the interaction between fluid and body, i.e., the flowfields around oscillating square cylinders both in cases of forced oscillation and wind-induced free oscillation. Computations are based on 3-dimensional (3D) LES using the standard Smagorinsky subgrid scale model. A very simple procedure is used to incorporate the influence of body motion on the flowfield. The accuracy of the computations using this procedure is examined by comparing them with the experimental results of Bearman et al. and Nakamura et al..
\end{abstract}

Keywords : $\quad$ wind-induced oscillation, forced oscillation, numerical analysis, $2 D$ square cylinder, negative aerodynamic force damping, LES

空力振動, 強制振動, 数值解析, 2 次元角柱, 空力負減衰, LES

\section{1. 序}

筆者らは，既報文1),2)において静止している 2 次元角柱ま わりの流れを Large Eddy Simulation(以降 LES)により解析 し, LES の 3 次元計算では, 通例の Smagorinsky Subgrid Scaleモデルを用いた場合であっても壁面風圧力や非定常空 気力特性に関して多くの点で実験とよく対応する解が得ら れることを示した。本報では，角柱を風向横方向(流入方 向および角柱スパン方向の 2 方向に直交する方向)に振動 させた場合について解析を行い，既往の実験文31.4)と比較し た結果を示す.

振動する 2 次元物体まわりに関しては，過去に差分法(以

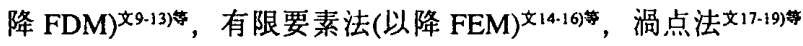
による解析が行われており，振動により生じる諸現象の再 現あるいは解明が試みられてきた。物体の振動を計算に組 み込む方法として，空間だけでなく時間も含めた座標变換 を行う一般曲線座標を用いる方法文9), 10)，ALE (Arbitrary Lagrangian-Eulerian)法を用いて物体の振動の影響を組み込む方 法文7), 15), 固定した計算格子内の境界面位固を移動させる
FAVOR (Fractional Area/Volume Obstacle Representation) 法文8)が あるＦEMではALE法がよく用いられ，FDMでは一般曲線 座標系が用いられることが多い。これに対して，本報で は，角柱の振動を計算に組み这む方法として，計算領域中 の角柱を振動させずに慣性力を外力項として流体の運動方 程式に加えるという考えの基に，計算格子を変形させない 簡便な方法を考案し，用いた。

過去に円柱や角柱等の断面形状の振動物体について上記 の種々の手法を用いた数值解析が行われてきた．振動円柱 まわりの流れの解析に関しては，田村ら文9がFDMによる $R e=3 \times 10^{3}, 1 \times 10^{4}$ の解析においてロックイン現象や瀜励振を

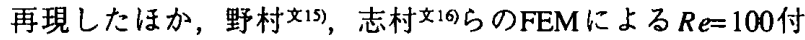
近の解析，珮点法による解析文か斿がある。また，側面で流 れが再付着する流れ方向に偏平な断面の角柱や $\mathrm{H}$ 型断面角 柱に関しても，流れ直交方向の並進振動文11),15\%，角柱軸ま わりの回転振動文10)，並進と回転を合わせた振動文19に関す る解析的検討が行われている。一方, 側面で再付着しない $1 \times 1$ 程度の辺長比の断面角柱が振動する場合について; 計
* 大成建設技術研究所 研究貝 (東京大学生産技術研究所 民間等共同研究員)

** 東京大学生産技術研究所 講師・工博

**** 東京大学生産技術研究所 教授・工博
Research Eng., Technology Research Center, Taisei Corporation (Joint Researcher, Institute of Industrial Science, Univ. of Tokyo)

Lecturer, Institute of Industrial Science, Univ. of Tokyo, Dr. Eng. Prof., Institute of Industrial Science, Univ. of Tokyo, Dr. Eng. 
算によって再現される負減衰等を実験值と比較して示した ものは. Launder, 加藤文11)，岡島ら文12)等比較的少数である。 1×1 断面角柱に関しては，Launder, 加藤女(1)は乱流エネル

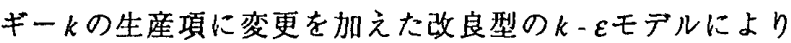
$R e \fallingdotseq 2 \times 10^{4}$ の条件の下で 2 次元解析を行い，揚力の位相や 㞬力振動させた場合の振動振幅について実験值と比較して いる。 また，岡島ら文12)は円柱および他の断面角柱の解析

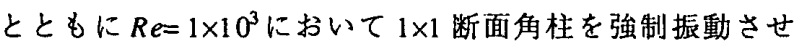
たFDMによる 2 次元の直接法による解析を行っている. 岡島らの解析では実験值との定量的な比較はなされていな いが，ストローハル数の計算値からロックイン現象が再現 されていることを確認するとともに，角柱に作用する揚力 と変位の位相差から空力負減衰が再現されていることが示

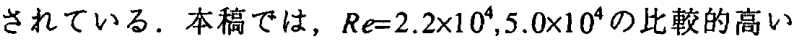
Reynolds 数を対象として，流れ直交方向に強制振動あるい は空力振動する $1 \times 1$ 断面角柱まわりの流れについて，通例 の Smagorinskyモデルに基づくLESによる 3 次元解析を行 い, 角柱に作用する揚力の大きさ，位相等に関して解析結 果を既往の実験結果文3),4)と詳細に比較する。

\section{2. 数值解析の概 要}

\section{1 解析対象}

解析条件の既要を図-1に示す．解析対象は乱れのない一 様流中に置いた正方形断面の 2 次元角柱であり，角柱を流

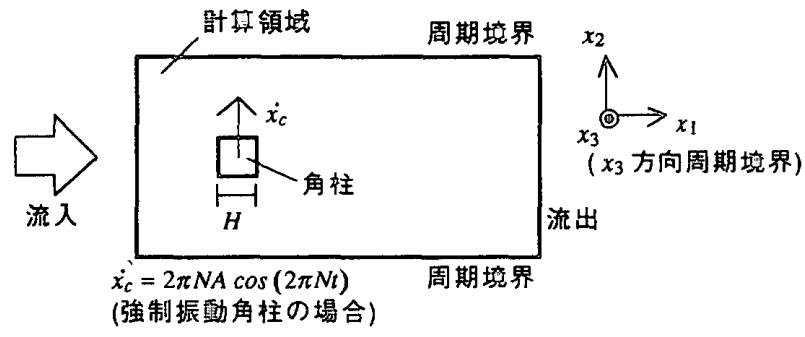

図-1 解析対象

表-1 計算ケース一覧

\begin{tabular}{|c|c|c|c|c|}
\hline \multirow{4}{*}{$\begin{array}{c}\text { 換筑風速 } \\
U_{r} \\
\left(U_{0} / N H\right)\end{array}$} & \multirow{4}{*}{ 配止角柱 } & \multicolumn{3}{|c|}{ 振動角柱 } \\
\hline & & \multicolumn{2}{|c|}{ 強制振獣 } & 空力振铔 \\
\hline & & \multicolumn{2}{|c|}{ 振幅 $A^{*}(A / H)$} & \multirow{2}{*}{$\begin{array}{l}S_{c} \\
1.36\end{array}$} \\
\hline & & 0.10 & 0.25 & \\
\hline -- & case 0 & & & \\
\hline 5.0 & & case 10 & -- & -. \\
\hline 7.0 & & case 11 & case 20 & ... \\
\hline 7.5 & & case 12 & case 21 & -- \\
\hline 8.0 & & case 13 & case 22 & -- \\
\hline 8.5 & & case 14 & case 23 & -- \\
\hline 9.0 & & case 15 & -- & case 30 \\
\hline 9.5 & & case 16 & -- & -.. \\
\hline 10.0 & & case 17 & case 24 & case 31 \\
\hline 11.0 & & - & case 25 & case 32 \\
\hline 12.0 & & -- & case 26 & case 33 \\
\hline
\end{tabular}

$U_{r}:$ 換I風速 $\left(=U_{0} / N H\right.$ ，角柱の無次元振動敏の逆致 $)$

$N$ : 角柱の根動数(記号参照)

$S_{c}$ : スクルートン数 $\left(S_{c}=2 m \delta / \rho H^{2} L_{3}\right)$
入直交 $\left(x_{2}\right)$ 方向に振動させる，振動は，角柱が $x_{2}$ 方向に正 弦波振動する場合(強制振動角柱)と，角柱が $x_{2}$ 方向にばね 支持されて作用する空力(揚为)により振動する場合(空力振 動角柱)の 2 通りである。

\section{2 解析ケース (表-1)}

静止角柱に関して1ケース(case0), 強制掁動角柱 15 ケ一 ス (case 10〜 17, case 20〜26), 空力振動角柱 4 ケース (case 30 〜33)の計 20 ケースの解析を行った。強制振動角柱では, $A^{*}(=A / H)=0.10,0.25$ の 2 種類の角柱の振動振偪について， ロックイン現象が生じる換算風速 $U_{r}\left(=U_{0} / N H\right)=5.0 \sim 12.0$ の範囲で 10 段階風速值を変化させて解析を行った。また， 空力振動角柱については，スクルートン数 $S_{c}\left(=2 m \delta / \rho H^{2} L_{3}\right)$ を中村らの実験奴に対応する 1.36 として, 角柱が負減衰振 動を生じる換算風速 $U_{r}=9.0 \sim 12.0$ の範囲の 4段階の風速值 での解析を行った。

\section{3 基礎方程式（表-2，表-3）}

既報丈1)、2) と同様に subgrid scale モデルとして標準 Smagorinskyモデルを用いたLESにより解析した(表-2).こ こでSmagorinsky定数 $C_{s}$ を 0.1 としている.レイノルズ数 $R e$ 〈記号〉

$x_{i}:$ 空間座櫂の 3 成分 ( $i=1$ : 主流方向, $i=2$ : 主流面角方向, $i=3$ : 角柱蚰方向), $u_{i}$ : 風嗃の $i$ 方向成分, $\quad L_{i}: i$ 方向の計算領域長さ $h_{i}: i$ 方向のメッシュ幅, $\quad N_{i}: i$ 方向のメッシュ数、 $f$ : 变数 $f$ の瞬時值, $\quad\langle f\rangle$ : 变数 $f$ の時間平均, $f^{\prime}$ : 時問平均からのずれ $(=\bar{f}-(\bar{f})), \bar{f}$ : 变敖 $f$ の梠子平均， $t$ : 時問, $n$ : 周波数, $\phi$ : 位相, $S(n)$ :パワースペクトル密度、 $h$ :LESの格子スケール((2.6)式)， $C_{s}$ : Smagorinsky 定数, $k_{S C S}$ : 乱流エネルギーの Subgrid Scale (SGS) 成分 ( (2.5)式), $v_{S G S}: S G S$ 滑怗性係敨 ( (2.3)式), $\quad v$ : 流体の動袩性係数, $R e:$ レイノルズ效 $\left(=U_{0} H(v), \quad \rho:\right.$ 流体密度, $S_{c}$ : スクルートン数 $\left(=2 m \delta / \rho H^{2} L_{3}\right) ， U_{0}$ : 流入平均風這, $U_{r}$ : 揬具風这 $\left(=U_{0} / N H\right) ， \quad H$ ：角柱一辺の長さ，

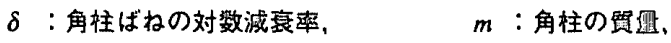

$N$ : 角柱の振動敏， $\quad A$ ：角柱の振動振幅、

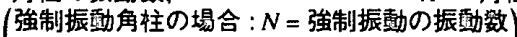
(空力振㽖角柱の場合 : $N=$ 角柱の固有振钦数)

$\ddot{x}_{c} ， \dot{x}_{c} ， x_{c}$ ：角柱の $x_{2}$ 方向の加速度, 速度, 变位,

$A^{*}$ : 角柱の無次元振動振幅 $(=A / H) ， \quad t^{*}$ : 無次元時間 $\left(=t U_{0} / H\right)$,

$N^{*}$ : 角柱の無次元振動数 $\left(=N H / U_{0}=1 / U_{r}\right)$.

$S t$ : ストローハル数( $F_{L}$ のスペクトルピークの周波数の無次元值)，

$U_{c r}: S f$ が $N^{*}$ と一致する時の $U_{r}, \quad S f$ : 角柱䋫止時の $S t$,

$p$ : 流九场の圧力(瞬時值), $\quad F_{L}$ : 撮力(眼時值),

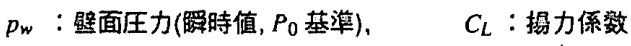

$P_{0}$ : 基集圧力 $\quad\left(=F_{L} /\left((1 / 2) \rho U_{0}^{2} L_{3}\right)\right)$,

(流れ堨全体の $p$ の空間平均值)， $\widetilde{C}_{L}: C_{L}$ の角柱振動敨成分、

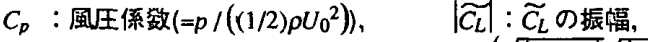

$R_{p}(r)$ : 生力 $\bar{p}$ の空間相䦎係数 $\left(=\left\langle p\left(r_{0}\right)^{\prime} p(r)^{\eta}\right) /\left(\sqrt{\left\langle p\left(r_{0}\right)^{12}\right]} \sqrt{\left(p(r)^{12}\right.}\right)\right)$,

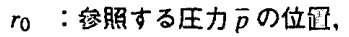

$h_{w}$ ：璧面に接するメッシュの幅(=垠小メッシュ幅)、

$x_{n}^{+}: x_{n}$ の壁座椤 $\left(=x_{n} u_{*} / v\right), \quad x_{n}$ : 壁面からの距離、

$u_{*}:$ 遊摖嗃度 $\left(=\sqrt{\tau_{w}}\right) ， \quad \tau_{w}$ : 壁面上に作用するせん断応力，

無次元化は $H, U_{0}, \rho$ を用いて行う. 
$\left(=U_{0} H / v\right)$ は，静止角柱および強制振動角柱では Bearman ら の実験文3とほほ対応する $2.2 \times 10^{4}$ とし，空力振動角柱では 中村らの実験対とほほ対応する $5.0 \times 10^{4}$ とした。また，空 力振動角柱のケースでは, 角柱は剛体であり，和方向にば ね支持されて並進振動のみするものとして通常の一質点の 運動方程式を用いた(表-3).

\section{4 角柱振動の計算への組み込み（図-1）}

本解析ではメッシュ系は変形させずに計算領域内の角柱 の位置を固定したまま，計算領域全体が振動しているもの として取り扱う。したがって，本解析で計算される流速 は角柱(座標系)の移動速度に対する相対速度であり，角柱 の振動は，角柱の加速度 $\ddot{x}_{c} に$ 流体密度 $\rho$ を乗じた慣性力 $\rho \ddot{x}_{c}$ と同じ絶対值をもつ逆符号の外力項 $-\rho \ddot{x_{c}}$ を計算領域の流体 全体に一様に加えることによって表現される(表-2)，表-2の 方程式系は通例のガリレイ変換に対して, 座標の移動速度 $\dot{x_{c}}$ の時間微分項 $\ddot{x}_{c}$ を付加した形式とみなし得る。また, この方程式系はHirtらの開発したALE法文のの方程式系を変 形し， $\dot{x_{c}}$ の空間微分項を0とした形と一致する，今回の計 算では角柱は $x_{2}$ 方向にのみ並進振動するため，而の方程式 にのみ計算領域全体に同じ值の慣性力ー $\rho \ddot{x}_{c}$ を加えている. 角柱が $x_{1}, x_{2}, x_{3}$ の全方向に振動する場合でも，本方法によ り計算を行うことができる。この場合は夜, $, \overline{u_{2}}, \overline{u_{3}}$ の運動方 程式に各方向の慣性力項を加えることになる。

\section{5 解析条件（表-4, 図-2）}

境界条件は $x_{2}$ および $x_{3}$ 方向が周期境界， $x_{1}$ 方向の流入 境界は $\overline{u_{1}}=1.0, \overline{u_{2}}=-\dot{x_{c}}, \overline{u_{3}}=0.0$ (流入乱れなし), 流出境界は $\overline{u_{1}}, \overline{u_{2}}, \overline{u_{3}}$ に関して $/ \partial x_{1}=0$ としている(表-4). 角柱壁面境界 には Werner Wengleによる linear-power law 型の 2 層モデル文 2).5)を用い，壁近傍では格子スケールhに wall damping function $\left(1-\exp \left(\left\llcorner x_{n}^{+} / 25\right)\right)\right.$ を乗じた。また，既報女1),2)と同様に HSMAC法のアルゴリズムを使用した。空間に関する離散 化には Piacsek Williams 型の 2 次量保存スキーム文6)使用し た。時間に関しては移流項に 2 次精度の Adams Bashforth ス キーム，搪散項に Crank Nicolsonスキームを用いた。時間 差分間隔は $\Delta t^{*}\left(=\Delta t U_{0} / H\right)=1 \times 10^{-3}$, 計算領域は $20 H\left(x_{1}\right) \times$

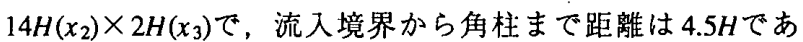
る.メッシュ分割は不等分割の $104\left(x_{1}\right) \times 69\left(x_{2}\right) \times 10\left(x_{3}\right)$ で メッシュ数は約 72,000 , 角柱近傍のメッシュ幅を $0.025 \mathrm{H}$ と した。

\section{6 データの探取}

振動角柱の各ケースともに，静止角柱(表-1の case0)の結 果を初期条件として計算を開始した。強制振動角柱では， 定常状態に達するまで無次元時間 $t *\left(=t U_{0} / H\right)$ で約 $150(1.5$ $\times 10^{5}$ ステップ)予備計算を行い，その後各ケースの角柱の 強制振動周期の約 10 周期分の間でデータを採取した。観
測時間は最も短い case 10 の場合, 無次元時間で約 50 , 最

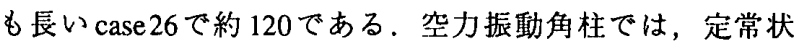
態に達するまで $t$ *で約 250 の予備計算を行った後各ヶー スの角柱の固有振動周期の約 10 周期分 (case 30,31,32,33で それぞれ約 90,100,110,120の無次元時間)の間でデー夕を探 取した。計算時間はVP2600(5GFLOPS)で1ケースあたり 最も短いcase 10 で 35 時間，最も長いcase 33 で 65 時間程度 である。

\section{3. 計算結果}

3.1 強制振動角柱

角柱を強制振動させたケース(case 10〜 17, case 20〜26)の

表-2 LES 基礎式

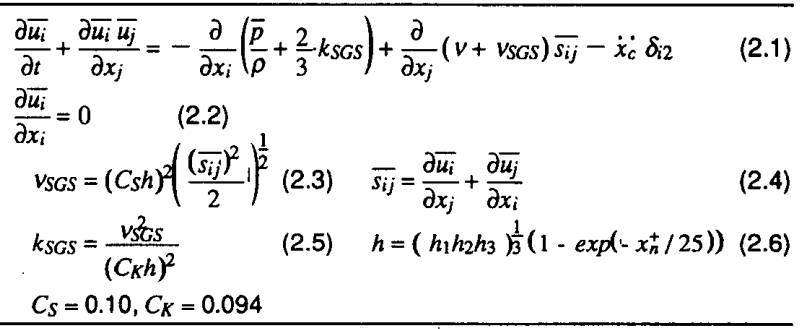

表-3 角柱の運動方程式

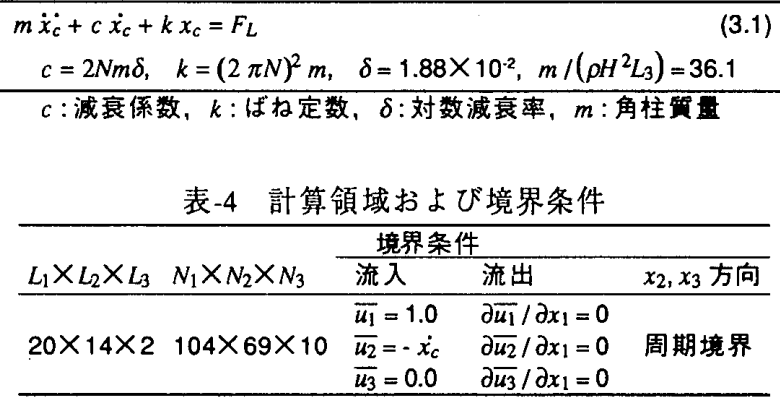

.表中の数值は $H, U_{0}$ で無次元化されたもの.

$\cdot \Delta t$ : 計算時間刻み $=0.001$

- $h_{w}$ ：角柱壁面に接するセルの大きさ $=0.025$

・暨面境界条件： linear-power 型の 2 屠モデル文21.5)

・流入は乱机なし。

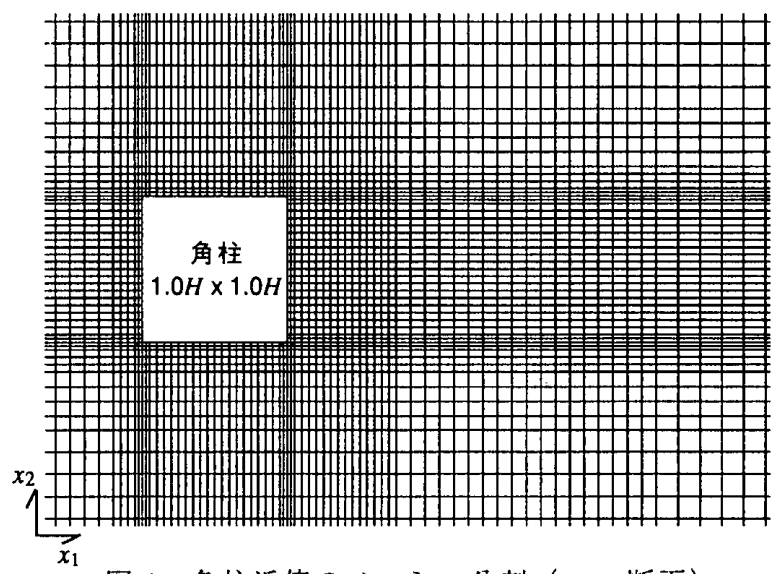

図-2 角柱近傍のメッシュ分割 $\left(x_{1}-x_{2}\right.$ 断面) 
結果を以下に示す.

\subsection{1 揚力変動の周波数}

角柱に作用する揚力係数 $C_{L}$ の時刻歴およびパワースペ クトル密度 $S(n)$ を図-3に示すせ川。この $C_{L}$ の变動はそれぞ れのカルマン渦発生周波数 $S t$ と対応している。図-3(1) は 静止角柱(case 0)扔よび振動角柱 (case 11: $A^{*}(=A / H)=0.10, U_{r}=$ 7.0)の場合の揚力の時刻歷を示しているが，静止角柱にお いてはStが約 17.3 となっているのに対し，振動角柱では St が角柱の振動数 $N^{*}\left(=1 / U_{r}\right)$ にロックインされて $1 / 7.0$ と なっている。このように $N^{*}$ と $S f$ (角柱静止時のストロー八 ル数 $S t)$ が近い場合，St が $N^{*}$ にロックインされる現象は $A^{*}=0.25$ の場合にも確認された。次に $N^{*}$ とSfの差が比較 的大きい場合の例について示す. 図-3(2) は，揚力係数 $C_{L}$ の $S(n)$ について振動振幅 $A^{*}=0.10$ の case 15,17 を case 0 と比 較したものである．而ケースともに強制振動周期の 10 周 期分のデータであるため，周波数の分解能が不充分である が, $N^{*}$ と角柱静止時のストローハル数Sfの差が大きいcase $15,17\left(U_{r}=9.0,10.0\right)$ では $N^{*}\left(=1 / U_{r}\right)$ 位置のピークが小さくな り， case17では，Sf およびN*のふたつの振動数位置でピー クが生じていることがわかる。すなわち， $N^{*}$ が $S f$ 付近に

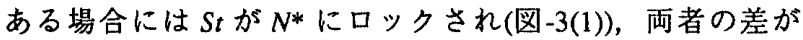
大きくなるとロックされていない(図-3(2)). これらの傾向 は実験結果と対応している。ここには示さないが，振動振 幅 $A^{*}=0.25$ の場合にも同様の傾向が確認できた。

\section{1 .2 揚力変動の大きさ}

角柱に作用する揚力係数の変動中の角柱振動数(N)に対応 する周波数成分 $\widetilde{C_{L}}$ の振幅 $\left|\widetilde{C_{L}}\right|$ を図-4に示す．図-4(1),(2) は それぞれ実験值文 ${ }^{4}\left(A^{*}=0.10,0.15\right)$ と計算值を示したもので ある．実験によると，| $\widetilde{C}_{L} \mid$ は $A^{*}=0.10,0.15$ ともに $U_{r}=U_{c r}$ 付

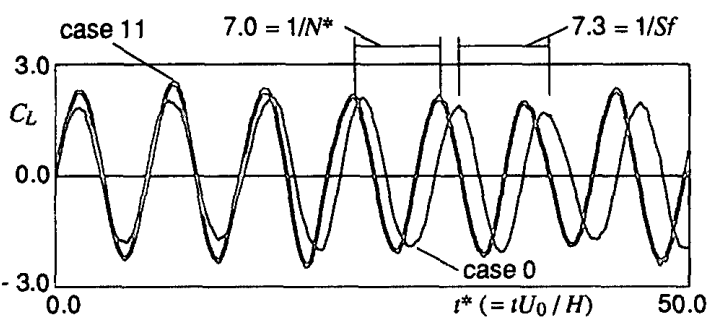

(1) 時刻歷：case 0,11 (静止角柱と $A^{*}=0.10, U_{r}=7.0$ )

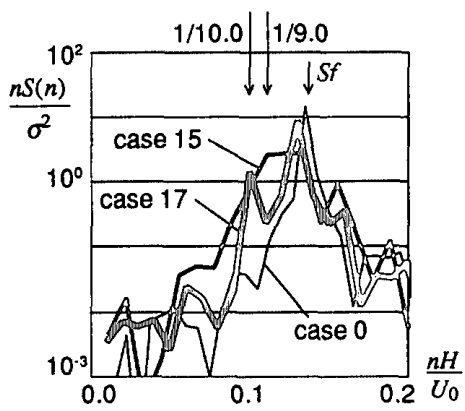

(2)バワースペクトル：case $0,15,17$

(静止角柱と $A^{*}=0.10$ の $U_{r}=9.0,10.0$ )

図-3 角柱に作用する揚力（強制振動角柱）
近で 2.0 程度のピーク値を示し，全般に $A^{*}=0.15$ の場合 $(\square)$ の方が $A^{*}=0.10$ の場合(国)よりも大きな值を示す(図-4(1)).

これらの傾向は計算值(図-4(2))においても同様である。す なわち, $A^{*}=0.10$ の場合， $\left|\widetilde{C_{L}}\right|$ のピーク值が 2.0 程度あるこ と，ピークを示す風速值 $U_{c r}$ を越えると $\left|\widetilde{C_{L}}\right|$ が減少する傾 向， $A^{*}$ が大きい $A^{*}=0.25$ の場合(図-4(2)の $\square$ )の方が $A^{*}=0.10$ の場合(闻)よりも $\left|\widetilde{C_{L}}\right|$ が大きな値を示すこと等, 計算値の 実験値との対応はよいと言える。ただし，計算值の方が実 験值に比べて $\left|\widetilde{C_{L}}\right|$ のピークがやや低風速側に位置してい

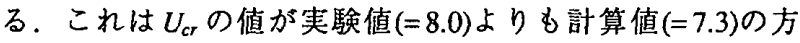
が小さいこと壮的原因のひとつであると考えられる，

3.1 .3 揚力変動の位相

(1) 揚力と角柱側面負圧の角柱変位に対する位相差

強制振動角柱(case 22: $A^{*}=0.25, U_{r}=8.0$ )の場合の, 角柱変 位と側面中央の負圧の絶対值 $\left|\overrightarrow{p_{w}}\right|$ の時刻歷を図-5に示す。 両波形のピーク間位置を比べると，変位に対する負圧の進

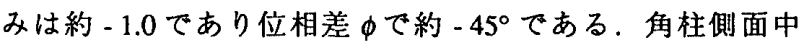
央の負圧の位相は角柱に作用する揚力 $F_{L}$ の位相にほほ対応

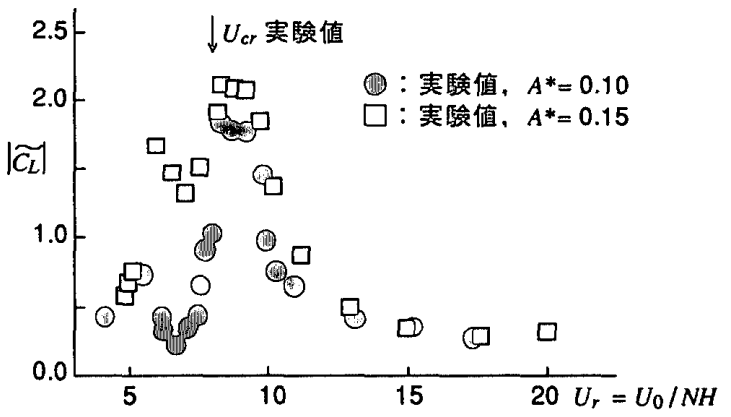

(1) 実験值文 4$)\left(A^{*}=0.10,0.15\right)$

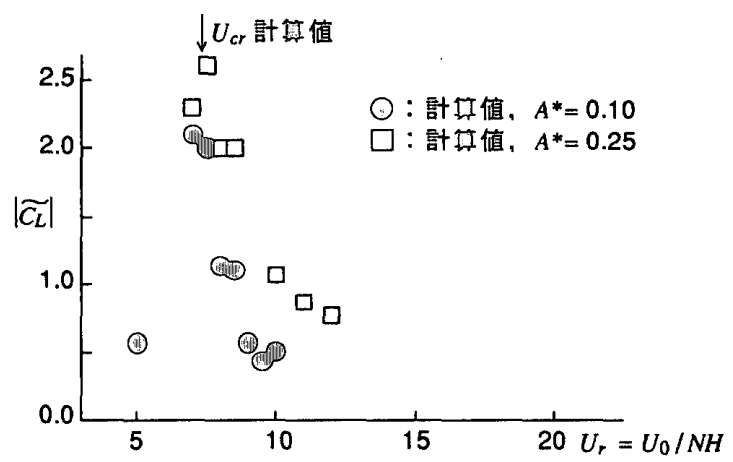

(2) 計算値 : case 10 17, 20 26 $\left(A^{*}=0.10,0.25\right)$ 図-4 揚力の角柱振動数成分（強制振動角柱）

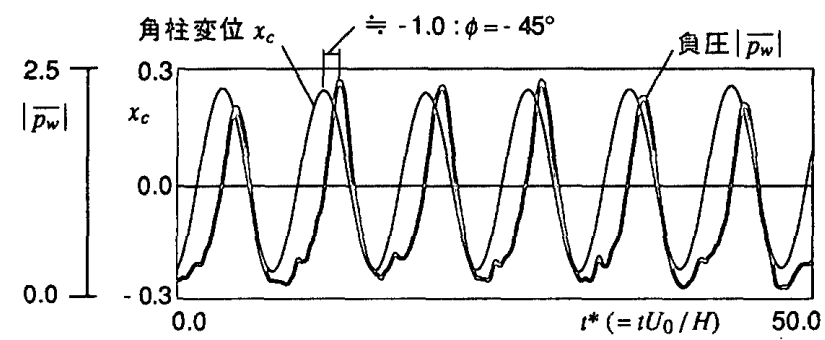

図-5 角柱変位と侧面負压： case $22\left(A^{*}=0.25, U_{r}=8.0\right)$ 
するもので，よく知られているように，変位に対する $F_{L}$ の 位相差 $\phi$ が正となる時に角柱に負減衰が生じる，全ケース にっいて，側面負圧および $F_{L}$ の変動中の角柱振動数成分の 角柱変位に対する位相差 $\phi$ (負圧(揚力)の位相 - 角柱変位の 位相)を図-6に示す壮1了。図-6(1)に $A^{*}=0.10$ の結果を，図-6(2) $に A^{*}=0.25$ の結果を示している，計算による側面負圧の位 相差(図-6(1)(2)の $\square) と F_{L}$ の位相差(図-6(1)(2)の口)を比較す ると， case $10\left(A^{*}=0.10, U_{r}=5.0\right)$ および case $25,26\left(A^{*}=0.25\right.$, $\left.U_{r}=11.0,12.0\right)$ を除き，他の $U_{r}=7.0 \sim 10.0$ の範囲で両者はほ とんど一致している，すなわち，このUrの範囲内では，側 面負圧の位相は揚力 $F_{L}$ の位相に対応しており，側面負圧の 位相差から負減衰の発生の有無を判断することが可能であ ると言える。

(2) 実験値との比較

今回行った計算は実験に扔いて角柱に負減衰が生じる範 囲を含んでおり，このような場合の $F_{L}$ の位相の正確な再現 は，渦励振・自励振動等の現象を正しく再現する上で不可 欠である， $F_{L}$ の位相差に対応する側面負圧の位相差を実験 值(-O-) と計算値( $\square$ )で比べると(図-6(1)(2)), $A^{*}=0.10$ で $U_{r}=7.0 \sim 9.0, A^{*}=0.25$ で $U_{r}=7.0 \sim 12.0$ の範囲で $\phi$ が負から 正へ急変するという実験結果が計算においてもよく再現さ れており， $A^{*}=0.10 て ゙ U_{r}$ が約 8 以上， $A^{*}=0.25$ で約 10 以上 において正の位相差，すなわち負減衰が生じていることが わかる。

(3) 角柱速度が最大值を示す時の風速抢よび圧力の分布 case 11,15 に扔いて角柱の速度が最大となる時の風速お よび圧力の分布を図-7に示す(図中上向きが角柱速度正). 図-6に示したように角柱変位と揚力の位相差 $\phi$ が, case11 ではー910であるのに対して case $15 て ゙ は ~ 80^{\circ}$ で約 $170^{\circ}$ の差 がある．風速べクトル図を見ると，角柱直後の渦が，case 11 では反時計回りに(図-7(1)(1)), case15では時計回りに生 ビている(図-7(2)(1)，圧力分布を比べると case11では，風

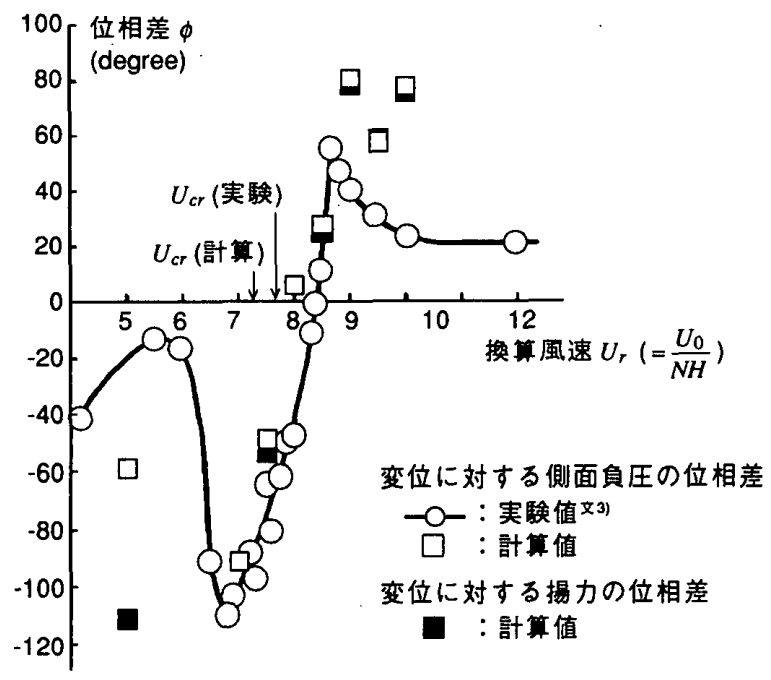

(1) 角柱の振幅 $A^{*}=0.10$

図-6 角柱変位に対する側面負圧と揚力の位相差（強制振動角柱）
向に対して右側の側面(図中下側)に負圧のピークがあり， 角柱に下向きの力が作用して振動を抑制しようとしている のに対して，case 15では，上向きの力が作用して动振しよ うとしていることが確認できる，図-7は強制振動角柱の場 合について示したものであるが，case15の場合には，角柱 をばね支持して空力振動させた時には負減衰が生じ，角柱 が自励振動することがわかる．流体の数值解析ではこのよ うな実験において計測が困難な压力の空間分布の瞬時值等 に関して詳細なデータを得ることができる。このような データの解析は空力振動と関係する流体現象のメカニズム を解明する上で極めて有用と考えられる．今後，これらの テータにより流れ場, 圧力場の非定常変化と固体の励振入 カニズムとの相互関連に関する検討を行っていく予定であ る.

3.1.4 角柱側面圧力の相関

静止角柱(case 0)と振動角柱(case 12, 21: $A^{*}=0.10,0.25, U_{r}=$ 7.5 )の場合の, 角柱風上隅か $50.125 H, 0.875 H$ 後方(压力参照 点位置 $\left.r_{0}=0.125 H, 0.875 H\right)$ の側面変動風圧と同じ側面の各点 の変動風圧の空間相関係数 $R_{p}(r)$ を図 -8 に示す. 図-8(1) か 静止角柱, 図-8(2)が振動角柱について計算值を実験值鬲 比較したものである，実験值によると，静止角柱では角柱 側面全体にわたって $R_{p}(r)$ が 0.9 以上と高くなっている(図8(1)の一○一).これに対して振動角柱の場合, 压力参照点位 置 $r_{0}=0.125 H$ では $R_{p}(r)$ が角柱風上隅付近から側面中央にか けて高く, 風下隅付近では 0.6 程度まで低下しており（図一 8(2)(1)の-O-)，r $r_{0}=0.875 H$ では $R_{p}(r)$ が角柱側面中央から風 上隅付近にかけて 0.6 程度まで低下している(図-8(2)(2)の 一一). 計算結果に扔いても，静止角柱ては，相関係数 $R_{p}(r)$ が全般に高い(図-8(1)(1)，(2)の一一)。 また， $r_{0}=0.125 H$ の場 合， $A^{*}=0.25$ の振動角柱(case21)では角柱風下隅付近の $R_{p}(r)$ は0.6以下まで低下しており(図-8(2)(1)の一), 角柱振動に より $R_{p}(r)$ が低くなる傾向が再現されている， $r_{0}=0.875 H$ の

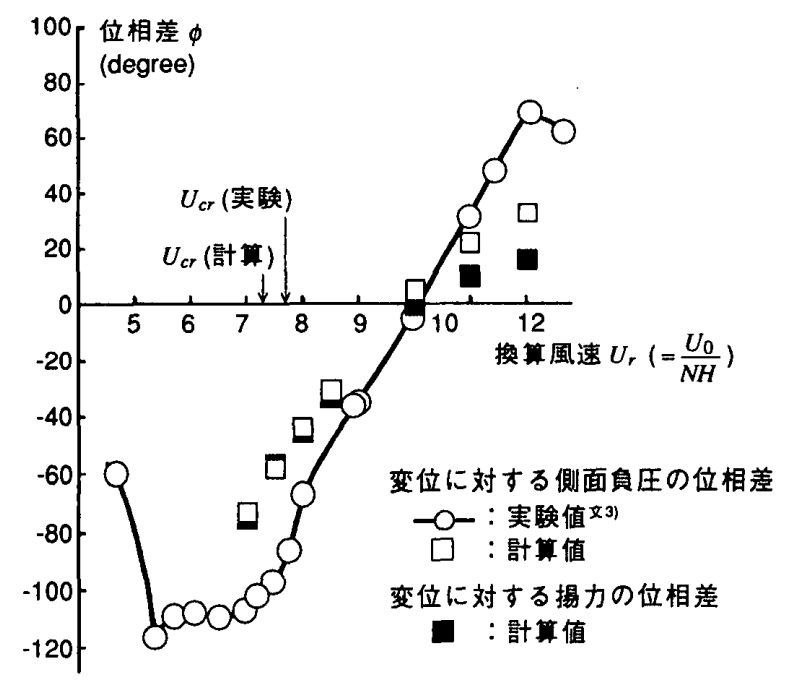

(2) 角柱の振幅 $A^{*}=0.25$ 
場合でも， $A^{*}=0.25$ の振動角柱の計算(case21)では角柱側面 中央から風上隅付近にかけて $R_{p}(r)$ が低い傾向はお拉むね再 現されている(図-8(2)(2)の 一)。一方，実験と同じ振動振 幅 $A^{*}=0.10$ の振動角柱(case 12)でも参照点から離れるのに

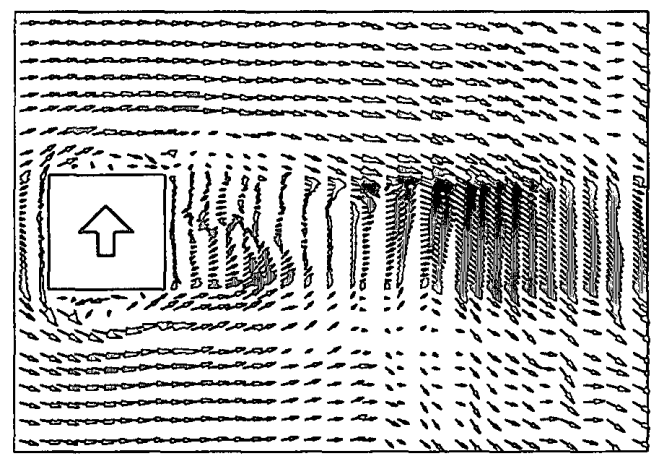

(1)風速ベクトル分布

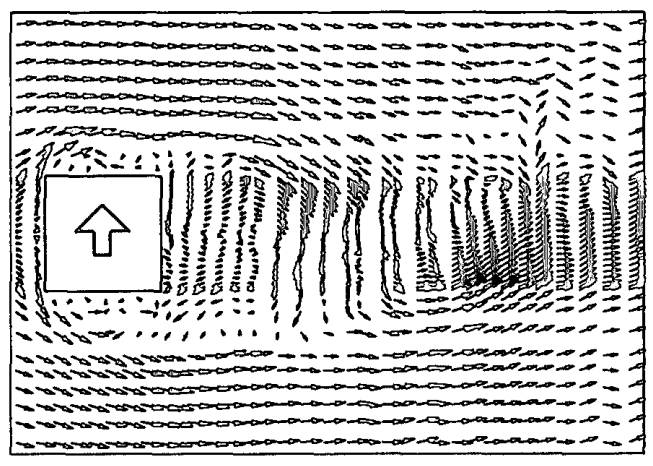

(1)風速ベクトル分布
伴い， $r_{0}=0.125 H$ の場合， $r_{0}=0.875 H$ の場合ともに $R_{p}(r)$ が 0.75 $\sim 0.80$ 程度まで低下しており(図-8(2)(1),(2)の一一)，角柱振 動により $R_{p}(r)$ が低くなる傾向は一応再現されているもの の, 全般に実験值に比べて計算值の方が $R_{p}(r)$ の低下は小さ

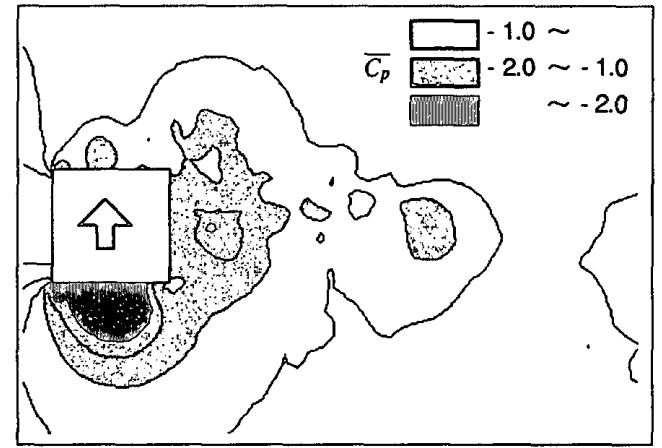

(2) 压力分布 $\overline{C_{p}}\left(=\bar{p} /\left((1 / 2) \rho U_{0}^{2}\right)\right)$

(1) case 11 $\left(A^{*}=0.10, U_{r}=7.0\right)$

(2) case 15 $\left(A^{*}=0.10, U_{r}=9.0\right)$

図-7風速㧍よび圧力の分布（強制振動角柱，瞬時値）

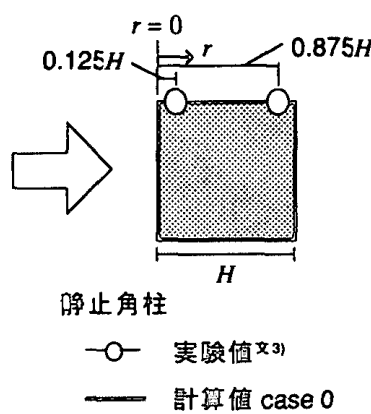

\section{振铺角柱}

-O- 寒崄值区3) $\left(A^{*}=0.10, U_{r}=7.9\right)$

- 計埴 case 12 $\left(A^{\star}=0.10, U_{r}=7.5\right)$

—計值 case 21 $\left(A^{*}=0.25, U_{r}=7.5\right)$

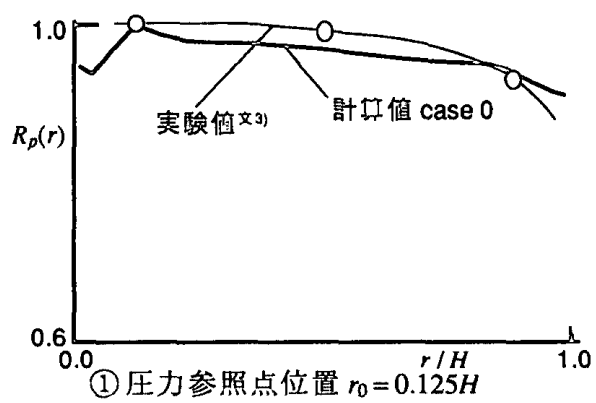

(1) 静止角柱
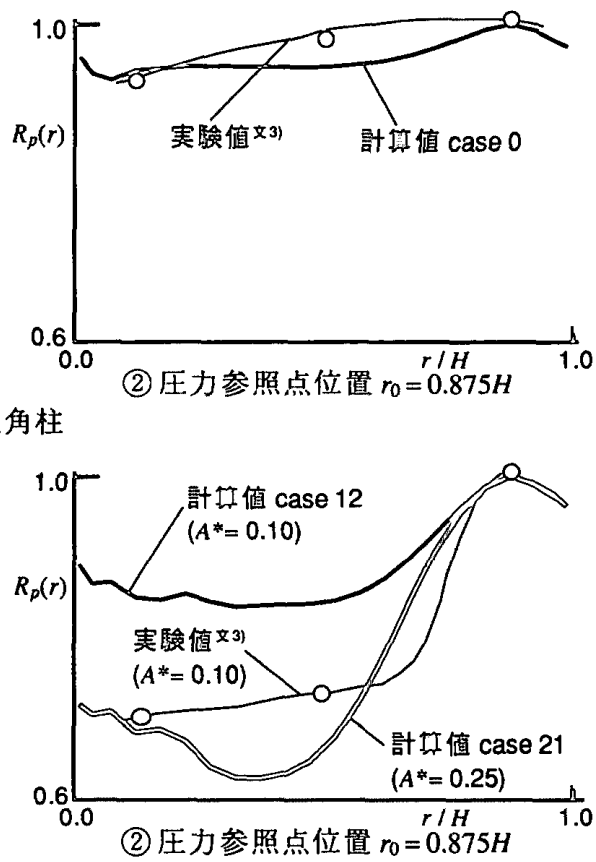

(2) 振動角柱

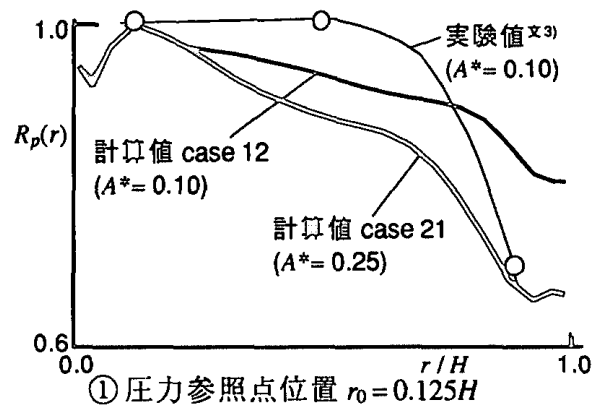

(r)の分布（強制振動角柱） 
い. 壁面圧力の相関の再現精度を向上させるためには，各 点の圧力の時間変動をより正確に捉える必要がある。

$A^{*}=0.10$ の場合の振動角柱の計算結果において角柱側面上 の空間相関が実験よりも高くなる原因として，LESの空間 フィルタによって計測点まわりにフィルタ幅の空間平均化 が行われていること，角柱スパン方向の計算領域長さが $2.0 H$ と不充分であること等が考えられる。したがって，角 柱壁面上のメッシュ分解能, 計算領域長さについて今後検 討を加える必要があると考えている。

\section{2 空力振動角柱}

流体の方程式と角柱の運動方程式を連成させて解いた空 力振動に関するケース(表-1の case 30〜33)の結果を以下に 示す.

\subsection{1 角柱振動および揚力変動の周波数}

case 33 $\left(U_{r}=12.0\right)$ の場合の角柱の振動速度 $\dot{x_{c}}$ および角柱に 作用する揚力係数 $C_{L}$ の時刻歴を図-9(1)に， case $31\left(U_{r}=10.0\right)$ の $\dot{x_{c}}$ および $C_{L}$ のパワースペクトル密度 $S(n)$ を図-9(2)に示 す，角柱の振動は定常に達しており(図-9(1))，ほほその固 有振動数で振動していること(図-9(2))が確認できる.すな わち， $\dot{x_{c}}$ の $S(n)$ では角柱の固有振動数 $N^{*}$ に対応するビー クの方が角柱静止時のストローハル数 $S f$ に対応するピーク よりはるかに大きい(図-9(2)). しかし， $C_{L}$ のS(n)ではSf(角 柱静止時のストローハル数)の振動数位置のピークも大き く(図-9(2)), 角柱は静止時のSfの振動数成分の力も大きく 受けていることがわかる。この傾向は，他の $U_{r}=9.0,11.0$ のケースについても同様である.

\subsection{2 振動振幅}

角柱の振動振幅の実験值文4)との比較を困-10に示す。図

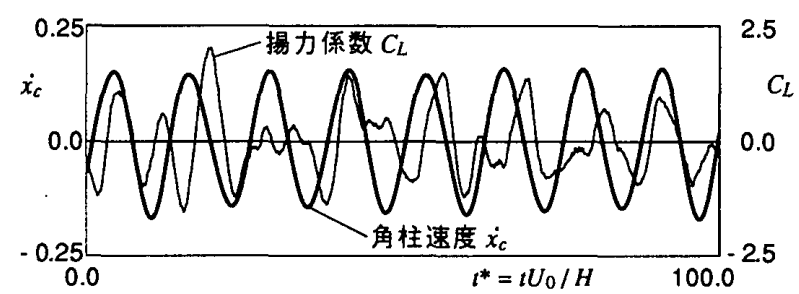

(1) 時刻歴： case $33\left(U_{r}=12.0\right)$

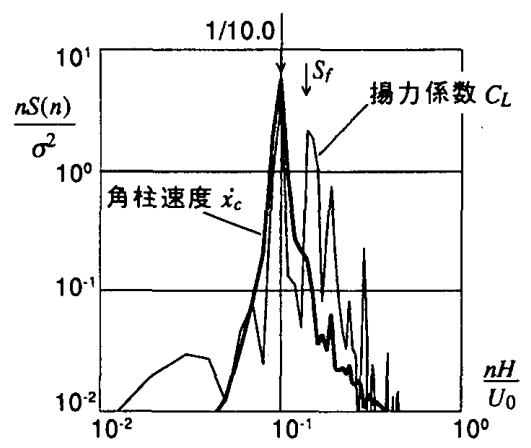

(2)パワースペクトル : case $31\left(U_{r}=10.0\right)$

図-9 角柱速度および揚力（空力振動角柱）
は換算風速 $U_{r}$ に対する角柱の無次元振幅 $\left(A^{*}(=A / H)\right)$ の変化 を示したものである．実験では換算風速 $U_{r}$ が $U_{c r}(=1 / S f=$ 角 柱静止時のストローハル数の逆数 $=8.0$ (実験值))以上となる と角柱の振動振幅が急速に増大していく．計算値でも， $A^{*}$

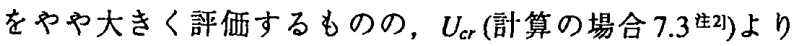
高い風速で急速に大きくなっていく傾向がよく再現されて いる，これは，次に示すように空力による負減衰が本解析 において再現されていることによるものである。

3.2 .3 揚力変動の位相

角柱変位に対する角柱側面負圧および揚力 $F_{L}$ の位相差 $\phi$ を図-11に示す，角柱側面負圧の $F_{L}$ のはいずれも $+15^{\circ} \sim+20^{\circ}$ 付近にある(図-11). したがっ て, 角柱に作用する $F_{L}$ の固有振動数成分から判断するかぎ りでは， $U_{r}=9.0 \sim 12.0$ において空力負減衰が生じ, 角柱が 自励振動していると言える。

\section{4. 結 論}

1）強制振動ならびに空力振動させた $1 \times 1$ 断面の角柱まわ りの乱流渦放出流れを標準 Smagorinskyモデルに基づく 3 次元 LESにより解析し，既往の実験と比較した。

2) 強制振動角柱の解析に関して以下の結論を得た。

(1)実験においてロックイン現象が生じる角柱振動数付

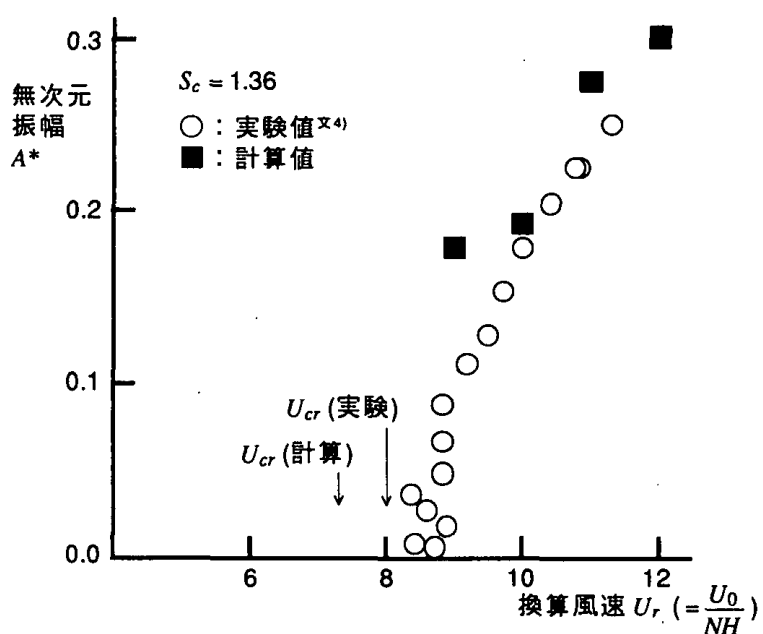

図-10 角柱の振動振幅（空力振動角柱）

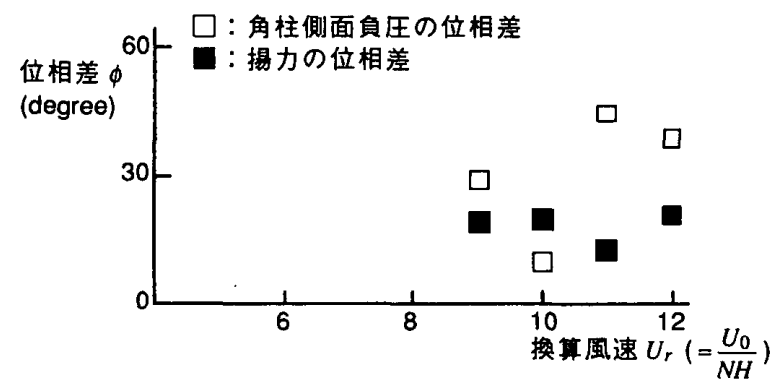

図-11 角柱変位に対する㑡面負圧と揚力の位相差

(空力振動角柱) 
近で, LESの解析においてもカルマン瀜発生振動数 がロックインされることを確認した。

(2)角柱に作用する揚力の大きさおよび角柱変位との位 相差の関係も計算で再現され，負減衰の発生も再現 されることを確認した。

(3)角柱側面に作用する変動風圧力の空間相関の分布に 関しても計算結果は実験の傾向を定性的には捉えて いる.

3）劦力振動角柱の解析では，空力により角柱に生じる負 減衰を再現し，換算風速の变化に伴う角柱の振動振幅 の変化に関して実験の傾向と良く一致することが示さ れた。

4) 本解析結果を詳細に検討すると，角柱静止時のストロー ハル数, 強制振動時の揚力変動の正の位相差について, やや実験値との差がみられた。これらの差異に関して はLESのSGS モデルの改良も含めて今後再検討する予 定である。

注

1]揚力変動の角柱振動数成分の振幅 $\left|\widetilde{C_{L}}\right|$ および角柱変位に対する㑡面負 压·掦力の位相差 $\phi$ は，強制振動角柱および空力振動角柱ともに，

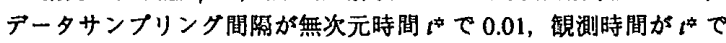
$10 / N^{\star}\left(N^{*}\right.$ :角柱の無次元振動数,記号参照)の間の変動波形をFFTによ クフーリ工夜換して求めた。 また，空力振動角柱の振動振幅は，钼測 時間 $\left(l^{*} て ゙ 10 / N^{*}\right)$ の間の波形の各ビーク值の平均值である.

2] 空力負诚度および角柱の不安定频動は，角柱解止時のストローハル数 $S f$ の逆数 $U_{c r}(=1 / S f)$ 付近からやや高い換算風速值で生じる，すなわ ち， $U_{c r}$ 付近で角柱に作用寸る揚力が角柱の振動を㧕制する方向から 顾振する方向人急变し，空力振動時の角柱の振動掁幅力增大する。 し たがって，Urに対する掦力・振動振幅などの变化を再現するために は，角柱猙止時に执いてストローハル效Sfを正礁に再現していなけ れドならない. Bearman らの実験他て $S f=17.7$, 中村らの実験妨では $S f=1 / 8.0$ であるのに対して，今回の計算值では $S f=1 / 7.3$ であ，実 験に比へててやや大きな值となっている．筆者らは前報吝において， Smagorinsky定数 $C_{s}$ ，影小メッシュ幅，角柱スバン方向の計算領域長 さを变えた場合の解析について示した，その結果によれば，Sfに対

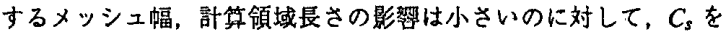
$0.10,0.13,0.20$ とするとそれぞれ $S f=17.3,17.6,1 / 8.1$ となる. このよ jに， $C_{s}$ を空間および時間に対して一定値とした場合には， $C_{s}=0.10$ 〜0.20の変化によって $S f=1 / 7.3 \sim 1 / 8.1$ の差が生しる. このC 関しては， $C_{s}$ を空間·時間の関数として取り扱う DynamicSGSモテル 丈200,21)の第入等で今後改善を加えていきたいと考えている。

\section{经考文献}

1）持田，村上，坂本：LESによる2次元角柱に作用する変動風圧力と流九 の 3 次元構造の解析 -2 次元計算と 3 次元計算の比較一, 日本建禁学 会權造系論文報告集，第453号，pp.47-55，1993 年 11 月.

2) 坂本,持田,村上,Rodi,W.：2次元角柱まわりの乱流洞放出流れに関す る LES と DSM, $k-\varepsilon$, 実験の比較，日本建等学会構造系論文集，第 459 号, pp.49-56, 1994 年 5 月.
3) Bearman, P. W. and Obasaju, E. D. : An experimental study of pressure fluctuations on fixed and oscillating square-section cylinders, Journal of Fluid Mechanics, vol.119, pp.297-321, 1982.

4) Nakamura, Y. and Mizota, T. : Unsteady lifts and wakes of oscillating rectangular prisms, Journal of the Engineering Mechanics Division, EM6, ASCE, pp.855-871, 1975.

5) Werner, $H$. and Wengle, $H$. : Large-eddy simulation of turbulent flow over and around a cube in plate channel, Proceeding of 8 th Symposium on Turbulent Shear Flows, p. 155, 1991.

6) Piacsek, S. A. and Williams, G. P. : Conservation properties of convection difference schemes, Journal of Computational Physics, vol. 6, pp. 392$405,1970$.

7) Hirt, C. W., Amsden, A. A. and Cook, J.L. : An arbitrary LagrangianEulerian computing method for all flow speeds, Journal of Computational Physics, vol.14, pp.227-253, 1974.

8) Hirt, C. W. and Sicilan, J. M. : A porosity technique for the definition of obstacles in rectangular cell meshes, 4 th International Conference on Numerical Ship Hydrodynamics, 1985.

9) Tamura, T.,Tsuboi, K. and Kuwahara, K. : Numerical simulation of unsteady flow pattems around a vibrating cylinder, AIAA-88-0128, 1988.

10）伊藤，田村,和田、桑原：振動する偏平矩形柱の空力特性，第7回数估 流体力学シンポジウム、,pp.403-406,1993，ほか.

11) Launder, B. E. and Kato, M. : Modelling flow-induced oscillations in turbulent flow around a square cylinder, Proceedings of Forum on Unsteady Flows, ASME Fluid Engineering Conference (FED-Vol.157), p.189, 1993.

12) Okajima, A., Kitajima, K. and Ueno, H. : Numerical study on wake patterns and aerodynamic forces of an oscillating cylinder with a circular and rectangular cross-section, Journal of Wind Engineering and Industrial Aerodynamics, vol.50, 1993.

13) Karanth, D., Rankin, G. W. and Sridhar, K. : Numerical simulation of flow past an oscillating cylinder, Proceedings of Forum on Unsteady Flows, ASME Fluid Engineering Conference (FED-Vol.157), pp.167-175, 1993.

14）野村：ALE法に基づく粘性流体と構造との相関問題の有限要素解析 手法，土本学会論文集，vol.416，pp.285-294，1990，ほか.

15) Nomura, T. and Hughes, T. J.R. : An arbitrary Lagrangian-Eulerian finite element method for interaction of fluid and a rigid body, Computer Methods in Applied Mechanics and Engineering95, pp.115-138，1992，ほか.

16) Shimura, M. and Zienkiewicz, O.C. : Interation Analysis between Structure and Fluid Flow Using the Direct Laplacian Method, Proceedings of 4 th International Conference on Computing in Civil and Building Engineering, pp.267-274, 1991, ほか.

17) 河井：円柱の滆励振機構についてー離散化渦法による数值シミュレー ション,第11回風工学シンボジウム, 1990.

18) Inamuro, T., Adachi, T. and Sakata, H. : Simulation of aerodynamic instability of bluff body, Journal of Wind Engineering and Industrail Aerodynamics, vol.46-47, 1993.

19) Shirato, H., Matsumoto, M. and Shiraishi, N. : Unsteady aerodynamic force characteristics on 2-D oscillating bluff body, Journal of Wind Engineering and Industrail Aerodynamics, vol.46-47, 1993.

20) Germano, M., Piomelli, U., Moin, P. and Cabot, W. H. : A dynamic subgridscaleeddy viscosity model, Phys. Fluids A3(7), pp.1760-1765, 1991.

21）持田,村上,富永,小林：Dynamic Subgrid-scale Model に基づくLESに よる 2 次元角柱周辺の流れの解析, 第 7 回数值流体力学シンポジウ A, pp.275-278, 1993. 